\title{
EFEK LAMA PERKECAMBAHAN TERHADAP SIFAT SENSORI DAN KADAR PROTEIN TERLARUT SUSU KECAMBAH KACANG MERAH (Sukarah) UNTUK REMAJA OBESITAS
}

\author{
The Effect Of Germination Time On Sensory Properties And Soluble \\ Protein Content In Red Bead Sprouts Milk (Sukarah) For Obese \\ Adolescents
}

\author{
Milla Nurjanati $^{1}$, Hery Winarsi ${ }^{1}$, Hidayah Dwiyanti ${ }^{2}$ \\ ${ }^{1}$ Ilmu Gizi, Fikes, Universitas Jenderal Soedirman \\ ${ }^{2}$ Jurusan Teknologi Pertanian Universitas Jenderal Soedirman \\ Email : nurjanatimilla10@gmail.com
}

\begin{abstract}
This study aims to determine the effect of germination on the nature of sensory and dissolved protein content of red bean sprouts milk. This non-factorial experimental study used a randomized block design. The factors studied were germination time: 0 hours, 8 hours, 16 hours, and 24 hours. Parameters tested were soluble protein content and sensory properties including color, flavor, taste, and viscosity. Sensory test using hedonic test and hedonic quality with 50 panelist. The results were analyzed using Friedman test followed by Multiple Comparison Test at $5 \%$ level, if there is significantly different. Effectiveness index were used to determine the best product. Data were analyzed using $F$ test at $95 \%$ confidence level. If there is significantly different continue with DMRT at 5\% level. The results was no effects of the length of time germination on soluble protein content, preferences on color, odor, and viscosity ( $p>0.05)$. The germination period had an effect on hedonic quality in the color, flavor, taste, and thickness of product $(p<0,05)$. The best sprout milk was for 16 hours. Thus, germination affect taste preferences, and hedonic quality in the color, flavor, taste, and viscosity of sukarah.
\end{abstract}

Keywords: red bean, germination, dissolved protein, sensory properties

\section{ABSTRAK}

Penelitian ini bertujuan mengetahui pengaruh lama perkecambahan terhadap sifat sensori dan kadar protein terlarut susu kecambah kacang merah. Eksperimental non faktorial menggunakan rancangan acak kelompok (RAK). Faktor yang diteliti adalah lama perkecambahan: 0 jam, 8 jam, $16 \mathrm{jam}$, dan $24 \mathrm{jam}$. Parameter yang diuji adalah kadar protein terlarut dan sifat sensori meliputi warna, aroma, rasa, dan kekentalan. Uji sensori menggunakan uji hedonik dan mutu hedonik dengan panelis sebanyak 50 orang. Hasil dianalisis menggunakan uji Friedman dilanjutkan Uji Banding Ganda pada taraf 5\%, jika ada pengaruh nyata. Untuk mengetahui sukarah terbaik dianalisis menggunakan indeks efektifitas. Data dianalisis menggunakan uji $\mathrm{F}$ pada taraf kepercayaan $95 \%$. Apabila ada pengaruh nyata dilanjutkan dengan Duncan's Multiple Range Test (DMRT) pada taraf $5 \%$. Hasil penelitian menunjukan tidak ada pengaruh lama perkecambahan terhadap kadar protein terlarut, kesukaan pada warna, aroma, dan kekentalan sukarah $(p>0,05)$. Susu kecambah terbaik adalah sukarah yang dikecambahkan selama 16 jam. Dengan demikian, perkecambahan mempengaruhi preferensi rasa, dan kualitas hedonis dalam warna, rasa, rasa, dan viskositas sukarah. Kata Kunci: Kacang merah, perkecambahan, protein terlarut, sifat sensori 


\section{PENDAHULUAN}

Masa remaja merupakan salah satu periode tumbuh kembang yang penting dan menentukan periode perkembangan berikutnya maka pemenuhan gizi yang tepat sangat penting (Montero et al., 2011). Usaha menghindari dan mengurangi obesitas banyak dilakukan salah satunya penggunaan obat-obatan, namun hal tersebut menimbulkan efek samping bagi tubuh. Salah satu strategi intervensi aman adalah melalui pangan fungsional. Pangan fungsional yang dimaksudkan adalah pangan yang mempunyai nilai fungsional untuk penderita obesitas, diantaranya yaitu pangan yang mampu menginduksi rasa kenyang, mengurangi nafsu makan, memodulasi metabolisme lipid dan menginduksi thermogenesis (Sunkara, 2014). Salah satu pangan nabati yang potensial dijadikan pangan fungsional untuk penderita obesitas adalah kacang merah.

Kacang merah diduga memiliki efek anti obesitas. Kacang merah memiliki kadar lemak yang jauh lebih rendah yaitu $0,25 \mathrm{~g} / 100 \mathrm{~g}$ dibanding kacang kedelai dan kacang tanah (USDA, 2010). Menurut Karisma
(2014) protein terlarut dalam kacang merah mecapai $0,71 \mathrm{~g} / 100 \mathrm{~g}$. Protein terlarut adalah suatu oligopeptida atau asam-asam amino yang mudah diserap oleh sistem pencernaan (Astawan, 2009).

Diantara zat gizi makro, proteinlah yang memberikan efek menekan appetite (selera makan) paling besar dan memacu efek satiety (rasa kenyang). Protein juga lebih menunjukan efek thermogenic dan favourable dibandingkan karbohidrat. Suatu penelitian substitusi yang menggunakan energi berasal dari protein daging babi dan protein kedelai sebesar 17-18\% masing-masing dalam 24 jam , ternyata protein kedelai menghasilkan energy expenditure 3\% lebih tinggi selama 24 jam. Sehingga protein kacang merah pun berpotensi seperti protein kedelai (Marsono, 2002).

Perkecambahan pada kacangkacangan dapat meningkatkan kadar protein terlarut, bioavailabilitas mineral, mengurangi kadar zat anti gizi (Winarsi, 2017). Lamanya perkecambahan yang berbeda mempengaruhi kandungan gizi dalam kacang-kacangan. Penelitian Pertiwi 
et al. (2013) membuktikan bahwa aktivitas antioksidan, total fenol, dan kadar vitamin $\mathrm{C}$ dalam kedelai hitam tertinggi pada lama perkecambahan 64 jam dibandingkan lama perkecambahan 32 jam, 40 jam, 48 jam, dan 56 jam. Penelitian Winarsi et al. (2010) menunjukan bahwa kandungan protein dalam isolat protein kecambah kedelai lebih tinggi dibanding isolat protein kedelai.

Pemanfaatan kecambah kacang merah yang saat ini dilakukan masih sebatas tepung kecambah kacang merah. Proses pengeringan pada pembuatan tepung dapat merusak zat aktif dan menurunkan aktivitas antioksidan pada kecambah kacang merah (Winarno, 2002), sehingga perlu pengolahan alternatif yang dapat mempertahankan manfaat fungsional dari kecambah kacang merah. Salah satu cara yang dapat dilakukan adalah dengan mengolah kecambah kacang merah menjadi susu kecambah kacang merah (sukarah). Atas dasar latar belakang tersebut di atas telah dilakukan penelitian dengan faktor perbedaan lama perkecambahan ( 8 jam, 16 jam, dan 24 jam) terhadap sifat sensori dan kadar protein terlarut dari sukarah.
Karena saat ini belum ada penelitian mengenai lama perkecambahan kacang merah yang memiliki daya terima tinggi ketika diolah dalam bentuk susu, begitupun dengan kadar protein sukarah. Adapun lama perkecambahan ditentukan dari hasil pra penelitian, ketika munculnya radikel pertama pada kacang merah yang dikecambahkan selama 8 jam, sedangkan kacang merah yang dikecambahkan lebih dari 24 jam sudah muncul akar.

Tujuan dari penelitian ini adalah untuk mengetahui pengaruh lama perkecambahan terhadap sifat sensori sukarah, dan kadar protein terlarut sukarah. Selain itu juga untuk mengetahui pengaruh lama perkecambahan optimal yang menghasilkan sukarah terbaik didasarkan pada aspek sensori dan kadar protein terlarut tertinggi.

\section{METODE}

\section{Lokasi dan Waktu Penelitian}

Penelitian ini dilaksanakan di Laboratorium Food Service Ilmu Gizi Fakultas Ilmu-ilmu Kesehatan dan Laboratorium Ilmu Teknologi Pangan Universitas Jenderal Soedirman pada bulan Mei- Juli 2017. 
J. Gipas, November 2018, Volume 2 Nomor 2

ISSN 2599-0152 eISSn 2599-2465 http://jos.unsoed.ac.id/index.php/jgps

Kacang merah jenis red kidney bean dari petani daerah Kalibagor Banjarnegara, larutan standar BSA 3,7 mg/5ml, larutan lowry A dan B.

Metode penelitian yang digunakan adalah metode penelitian experimental non faktorial. Rancangan penelitian menggunakan RAK (Rancangan Acak Kelompok) dengan 4 macam perlakuan dan 5 kali ulangan. Perlakuan yang akan diteliti, yaitu : R0: tanpa dikecambahkan; R1: dikecambahkan selama 8 jam; R2: dikecambahkan selama 16 jam; R3: dikecambahkan selama 24 jam.

\section{Variabel Penelitian}

Variabel yang diamati adalah sifat sensori dan kadar protein terlarut. Variabel sensori yaitu warna, rasa, aroma, dan kekentalan.

\section{Analisis Data}

Hasil yang diperoleh dari data kadar protein dianalisis dengan menggunakan uji $\mathrm{F}$ pada taraf kepercayaan $95 \%$ dan apabila ada pengaruh yang nyata dilanjutkan dengan Duncan's Multiple Range Test (DMRT) pada taraf 5\%. Analisis variabel sensoris dianalisis menggunakan uji Friedman dan jika menunjukan pengaruh yang nyata dilakukan Uji Banding Ganda pada taraf 5\%. Untuk mengetahui sukarah yang terbaik didasarkan pada aspek sensori dan kadar protein dianalisis menggunakan indeks efektifitas. 


\section{HASIL DAN PEMBAHASAN}

\section{Sifat Sensori Susu Kecambah Kacang Merah}

\section{a. Mutu Hedonik Warna}

Warna merupakan sensasi sensoris karena adanya rangsangan dari seberkas energi radiasi yang jatuh ke indra penglihatan (Aprilianti, 2010). Uji organoleptik yang dinilai pertama kali terhadap suatu produk dengan menggunakan mata yaitu dengan melihat warna produk, karena secara visual warna tampil terlebih dahulu dalam penentuan produk makanan (Fellows, 2002).

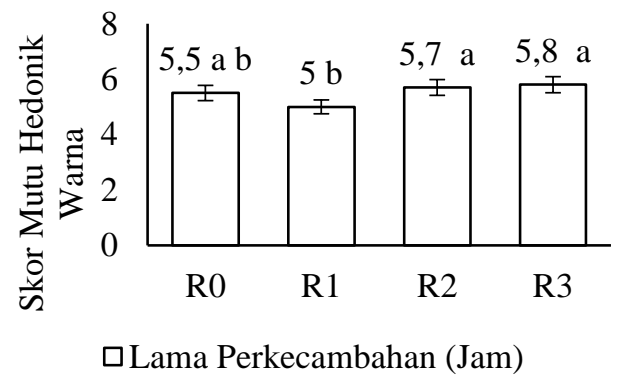

\section{Gambar 4.1. Nilai Rata-rata Mutu Hedonik Warna Sukarah pada Perlakuan Lama Perkecambahan}

Keterangan:

$\mathrm{R} 0=$ Kontrol; R1 = Sukarah dengan lama perkecambahan 8 jam; R2 = Sukarah dengan lama perkecambahan 16 jam; R3 = Sukarah dengan lama perkecambahan 24 jam. Skor:Warna: (1) Coklat; (2) Coklat Kekuningan; (3) Kuning; (4) Sedikit Kuning; (5) Putih Kecoklatan; (6) Putih kekuningan; (7) Putih. $n=50$. Angka yang diikuti huruf yang sama menunjukkan tidak berbeda nyata pada DMRT 5\%; Angka yang diikuti huruf yang berbeda menunjukkan ada perbedaan yang nyata pada DMRT 5\%.
Uji

Friedman

menunjukkan terdapat pengaruh lama perkecambahan terhadap mutu hedonik warna sukarah ( $\mathrm{p}<0,05)$. Hasil uji banding ganda menunjukkan terdapat perbedaan antar perlakuan (Gambar 4.1). Sukarah yang dikecambahkan selama 8 jam mempunyai warna lebih gelap (5) dibandingkan sukarah yang dikecambahkan selama 16 jam $(5,7)$ dan 24 jam $(5,8)$ yang berwarna lebih terang atau mendekati putih. Hal tersebut kemungkinan disebabkan kandunganan tanin dalam sukarah yang dikecambahkan selama 8 jam masih tinggi. Tanin merupakan senyawa polifenol yang bila bereaksi dengan besi akan memberikan warna gelap. Senyawa ini banyak terdapat dalam kacang-kacangan. Tanin dalam biji yang jumlahnya tinggi menimbulkan rasa pahit dan warna gelap (Winarsi, 2017). Diperkuat oleh Mawardi et al. (2016) yang melaporkan bahwa warna air seduhan daun sirsak yang berwarna kuning kegelapan berhubungan dengan kadar tanin yang terkandung di dalam daun 
sehingga semakin besar kadar tanin yang terkandung di dalam minuman fungsional daun sirsak maka semakin gelap pula warna air seduhan minuman fungsional daun sirsak yang dihasilkan. Winarsi (2017) menyatakan bahwa perkecambahan dapat menurunkan kadar tanin dalam kacangkacangan.

\section{b. Mutu Hedonik Aroma}

Aroma merupakan salah satu faktor penentu kualitas produk makanan. Pada industri pangan pengujian aroma dianggap penting karena dengan cepat memberikan hasil penilaian diterima atau tidaknya suatu produk. Timbulnya aroma atau bau karena zat bau tersebut bersifat volatil (menguap), sedikit larut dalam air dan lemak (Winarno, 2004).

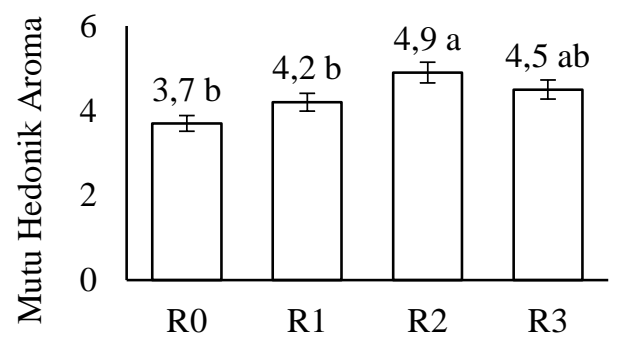

$\square$ Lama Perkecambahan (Jam)

\section{Gambar 4.2. Mutu Hedonik Aroma Sukarah pada Perlakuan Lama Perkecambahan}

Keterangan:

$\mathrm{R} 0=$ Kontrol; $\mathrm{R} 1=$ Sukarah dengan lama perkecambahan 8 jam; R2 = Sukarah dengan lama perkecambahan 16 jam; R3 = Sukarah dengan lama perkecambahan 24 jam. Skor Aroma: (1) Amat sangat langu; (2) Sangat langu; (3) Langu; (4) Sedikit langu; (5) Sedikit sekali langu; (6) Antara langu dan tidak langu; (7) Tidak ada langu. $\mathrm{n}=50$. Angka yang diikuti huruf yang sama menunjukkan tidak berbeda nyata pada DMRT 5\%; Angka yang diikuti huruf yang berbeda menunjukkan ada perbedaan yang nyata pada DMRT 5\%.

Uji Friedman menunjukkan terdapat pengaruh lama perkecambahan terhadap mutu hedonik aroma sukarah $(\mathrm{p}<0,05)$. Hasil uji banding ganda menunjukkan terdapat perbedaan mutu aroma sukarah (Gambar 4.2), semakin lama waktu perkecambahan maka aroma bau langu semakin sedikit. Penurunan bau langu disebabkan karena perkecambahan mampu mengurangi aroma langu. Kedelai dan kacang-kacangan lain termasuk kacang merah mengandung enzim lipoksigenase atau lipoksidase. Enzim ini mengkatalis asam lemak tidak jenuh yang teroksidasi oleh oksigen molekuler, sehingga menyebabkan timbulnya ketengikan dan bau langu atau beany flavor. Enzim lipoksigenase 
atau lipoksidase diperlukan untuk perkecambahan, sehingga dengan perkecambahan dapat mengurangi bau langu tersebut (Pertiwi et al., 2013).

\section{c. Mutu Hedonik Rasa}

$$
\text { Rasa didefinisikan }
$$

sebagai rangsangan yang ditimbulkan oleh bahan yang dimakan, terutama yang dirasakan oleh indera pengecap. Rasa merupakan faktor yang penting dalam menentukan keputusan bagi konsumen meskipun parameter lain nilainya baik, jika rasa tidak enak atau tidak disukai, maka produk akan ditolak. Ada empat jenis rasa dasar yang dikenali yaitu manis, asin, asam, dan pahit, sedangkan rasa lainnya merupakan perpaduan rasa dasar (Fellow, 2000).

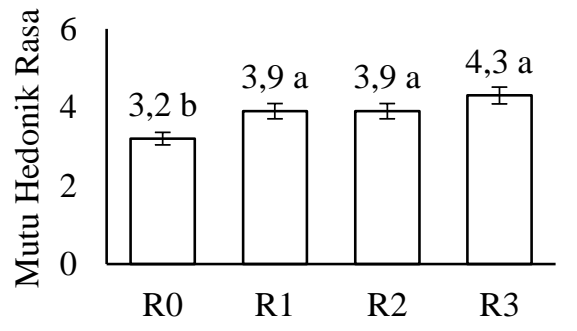

$\square$ Lama Perkecambahan (Jam)

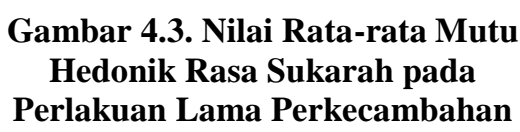

Keterangan:

$\mathrm{R} 0=$ Kontrol; $\mathrm{R} 1=$ Sukarah dengan lama perkecambahan 8 jam; R2 = Sukarah dengan lama perkecambahan 16 jam; R3 = Sukarah dengan lama perkecambahan 24 jam. Skor Rasa: (1) Hambar; (2) Tidak manis; (3) Sedikit sekali rasa manis; (4) Sedikit manis; (5) Manis; (6) Sangat Manis; (7) Amat sangat manis. $n=50$. Angka yang diikuti huruf yang sama menunjukkan tidak berbeda nyata pada DMRT 5\%; Angka yang diikuti huruf yang berbeda menunjukkan ada perbedaan yang nyata pada DMRT 5\%.

\section{Uji Friedman}

menunjukkan terdapat pengaruh lama perkecambahan terhadap mutu hedonik rasa sukarah ( $<<0,05$ ). Hasil uji banding ganda menunjukkan bahwa ada perbedaan antara R0 yaitu susu dari kacang merah yang tidak dikecambahkan dengan R1, R2, dan R3 (Gambar 4.3), semakin lama waktu perkecambahan, rasa sukarah semakin manis. Rasa manis ini timbul dari perubahan pati menjadi maltosa selama terjadinya perkecambahan. Winarno (2002) menyatakan, selama terjadinya perkecambahan, pati diubah menjadi dekstrin atau bagian yang lebih kecil lagi yaitu dalam bentuk gula maltosa. Selain itu adanya penambahan gula 5\% 
juga mempengaruhi rasa manis sukarah.

d. Mutu Hedonik Tekstur

Tekstur merupakan gambaran mengenai atribut bahan makanan yang dihasilkan melalui kombinasi sifat-sifat fisik dan kimia, diterima secara luas oleh sentuhan, penglihatan dan pendengaran (Lewis, 2000).

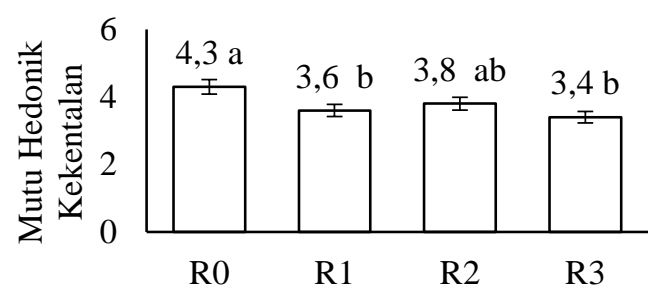

口Lama Perkecambahan (Jam)

\section{Gambar 4.4. Nilai Rata-rata Mutu Hedonik Kekentalan Sukarah pada Perlakuan Lama Perkecambahan} Keterangan:

$\mathrm{R} 0=$ Kontrol; R1 = Sukarah dengan lama perkecambahan 8 jam; R2 = Sukarah dengan lama perkecambahan 16 jam; R3 = Sukarah dengan lama perkecambahan 24 jam. Skor Kekentalan: (1) Encer Sekali; (2) Encer; (3) Tidak Kental; (4) Sedikit kental; (5) Kental; (6) Sangat Kental; (7) Amat Sangat kental. $\mathrm{n}=50$. Angka yang diikuti huruf yang sama menunjukkan tidak berbeda nyata pada DMRT 5\%; Angka yang diikuti huruf yang berbeda menunjukkan ada perbedaan yang nyata pada DMRT $5 \%$.

$$
\text { Uji Friedman }
$$

menunjukkan adanya pengaruh lama perkecambahan terhadap mutu hedonik kekentalan sukarah $(\mathrm{p}<0,05)$. Hasil uji banding ganda menunjukkan sukarah yang dikecambahkan secara nyata mempuyai kekentalan yang lebih rendah dibandingkan sukarah yang tidak dikecambahkan (Gambar 4.4). Kekentalan yang semakin berkurang disebabkan karena terjadinya hidrolisis pati selama proses perkecambahan oleh enzim $\alpha$-amilase. Enzim tersebut dibentuk pada awal perkecambahan oleh asam giberilik (Suarni et al., 2007).

Susu yang tidak dikecambahkan memiliki pati yang tinggi sehingga teksturnya lebih kental. Hal tersebut terjadi karena pati akan mengalami gelatinisasi jika diberi perlakuan panas, granula pati tidak larut dalam air dingin tetapi mengembang dalam air hangat atau panas yang disebut dengan proses gelatinisasi. Pada saat larutan pati mencapai suhu gelatinisasi maka granula-granula pati pecah dan molekul-molekul pati keluar dan terlepas dari granula serta masuk dalam sistem larutan. Hal ini menyebabkan viskositas tinggi (Rakhmawati, 
2012). Hasil penelitian ini selaras dengan penelitian Yua Wea et al. (2014) yang menunjukkan bahwa semakin lama waktu perkecambahan maka susu kecambah kacang hijau yang dihasilkan semakin encer.

e. Kesukaan Warna

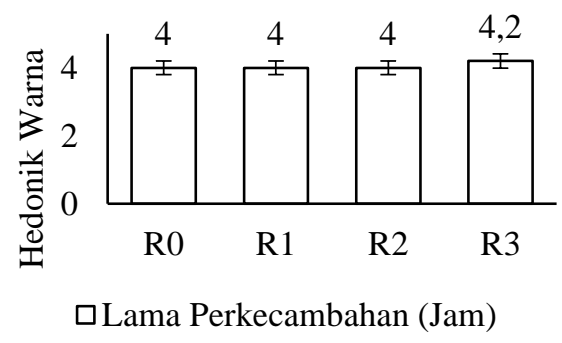

Gambar 4.5. Nilai Rata-rata Kesukaan Warna Sukarah pada Perlakuan Lama Perkecambahan Keterangan:

$\mathrm{R} 0=$ Kontrol; $\mathrm{R} 1=$ Sukarah dengan lama perkecambahan 8 jam; R2 = Sukarah dengan lama perkecambahan 16 jam; R3 = Sukarah dengan lama perkecambahan 24 jam. Skor: $1=$ Amat sangat tidak suka; $2=$ Sangat tidak suka; $3=$ Tidak Suka; $4=$ Antara suka dan tidak suka; $5=$ Suka; $6=$ Sangat suka; $7=$ Amat sangat suka; $\mathrm{n}$ $=50$. Angka yang diikuti huruf yang sama menunjukkan tidak berbeda nyata pada DMRT 5\%; Angka yang diikuti huruf yang berbeda menunjukkan ada perbedaan yang nyata pada DMRT $5 \%$.

Hasil uji Friedman menunjukkan tidak ada pengaruh lama perkecambahan terhadap kesukaan pada warna sukarah ( $>0,05) \quad$ (Gambar 4.5). Kemungkinan sebagian besar panelis memberikan respons kesukaan warna yang sama karena sukarah antar perlakuan memiliki warna dasar yang sama yaitu putih. Hasil tersebut diperkuat dengan hasil nilai mutu hedonik warna yang tidak berbeda jauh yaitu rentang 5,5-5,8 (putih kecoklatanputih kekuningan) (Gambar 4.1). Selaras dengan penelitian Ojha et al. (2014) yang menunjukkan bahwa tidak ada pengaruh pada warna antara tahu dari susu kedelai yang dikecambahkan dengan yang tidak dikecambahkan, karena keduanya memiliki warna dasar yang sama yaitu putih sehingga sangat mirip. Murugkar (2014) menegaskan tidak ada pengaruh perkecambahan terhadap kesukaan warna susu kecambah kedelai karena susu dari kedelai yang dikecambahkan dengan yang tidak dikecambahkan memiliki warna yang serupa.

Berbeda halnya dengan Pertiwi et al. (2010) bahwa lama perkecambahan mempengaruhi kesukaan warna susu kecambah kedelai hitam. Semakin singkat lama perkecambahan menurunkan tingkat kesukaan pada warna karena warnanya yang terlalu pekat. Hal itu terjadi karena 
pigmen pada kulit ari salah satunya antosianin kecambah kedelai hitam seluruhnya larut ketika dilakukan ekstraksi. Semakin lama perkecambahan warna susu kecambah kedelai hitam semakin cerah.

\section{f. Mutu Hedonik Aroma}

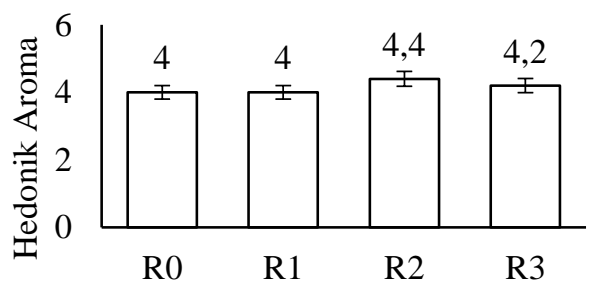

$\square$ Lama Perkecambahan (Jam)

Gambar 4.6. Nilai Rata-rata

Kesukaan Aroma Sukarah pada Perlakuan Lama Perkecambahan Keterangan:

$\mathrm{R} 0$ = Kontrol; $\mathrm{R} 1$ = Sukarah dengan lama perkecambahan 8 jam; R2 = Sukarah dengan lama perkecambahan 16 jam; R3 = Sukarah dengan lama perkecambahan 24 jam. Skor: $1=$ Amat sangat tidak suka; $2=$ Sangat tidak suka; 3 = Tidak Suka; 4 = Antara suka dan tidak suka; $5=$ Suka; $6=$ Sangat suka; 7 = Amat sangat suka; $\mathrm{n}$ $=50$. Angka yang diikuti huruf yang sama menunjukkan tidak berbeda nyata pada DMRT 5\%; Angka yang diikuti huruf yang berbeda menunjukkan ada perbedaan yang nyata pada DMRT 5\%.

Hasil uji Friedman menunjukkan tidak terdapat pengaruh lama perkecambahan terhadap kesukaan pada aroma sukarah ( $p>0,05)$ (Gambar 4.6). Kemungkinan karena dilihat dari hasil nilai mutu hedonik rentangnya tidak terlalu jauh yaitu 3,7-4,8 (sedikit langu-sedikit sekali langu), baik sukarah yang dikecambahkan maupun tidak dikecambahkan masih memiliki bau langu (Gambar 4.2) tetapi ada kecendrungan aroma susu yang dikecambahkan lebih disukai panelis dibanding dengan yang tidak dikecambahkan.

Berbeda dengan Pertiwi (2010) yang menyatakan terdapat pengaruh lama perkecambahan terhadap kesukaan pada aroma susu kecambah kedelai hitam. Aroma yang paling disukai adalah susu dengan lama perkecambahan terlama (64 jam) karena dengan dilakukan perkecambahan mampu mengurangi aroma langu secara nyata.

g. Mutu Hedonik Rasa

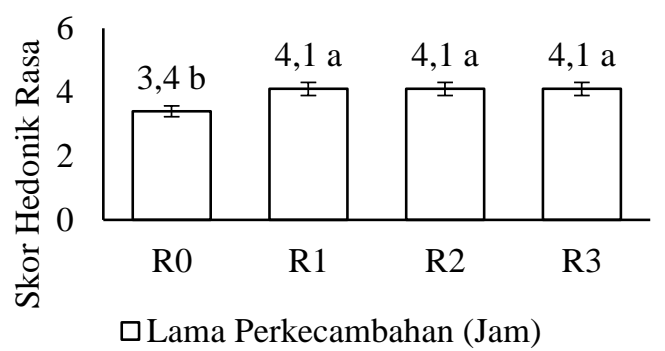

Gambar 4.7. Nilai Rata-rata

Kesukaan Rasa Sukarah pada Perlakuan Lama Perkecambahan Keterangan:

$\mathrm{R} 0$ = Kontrol; R1 = Sukarah dengan lama perkecambahan 8 jam; R2 = Sukarah dengan lama perkecambahan 16 jam; R3 = Sukarah dengan lama 
perkecambahan 24 jam. Skor: $1=$ Amat sangat tidak suka; $2=$ Sangat tidak suka; 3 = Tidak Suka; 4 = Antara suka dan tidak suka; $5=$ Suka; $6=$ Sangat suka; $7=$ Amat sangat suka; $\mathrm{n}$ $=50$. Angka yang diikuti huruf yang sama menunjukkan tidak berbeda nyata pada DMRT 5\%; Angka yang diikuti huruf yang berbeda menunjukkan ada perbedaan yang nyata pada DMRT 5\%.

\section{Hasil uji Friedman} menunjukkan ada pengaruh lama perkecambahan terhadap kesukaan pada rasa sukarah $(\mathrm{p}<0,05)$. Hasil uji banding ganda menunjukkan terapat perbedaan antar perlakuan, panelis lebih menyukai rasa sukarah yang dikecambahkan dibandingkan yang tidak dikecambahkan, kemungkinan karena semakin lama perkecambahan rasa sukarah semakin manis (Gambar 4.7). Khas kacang-kacangan adalah rasa pahit termasuk pada kacang merah. Rasa pahit dihasilkan karena adanya senyawa-senyawa glikosida terutama saponin dan sapogenol. Perkecambahan akan menurunkan senyawa-senyawa tersebut sehingga rasa pahit berkurang (Winarsi, 2017).

$$
\text { Perkecambahan dapat }
$$

meningkatkan sifat sensori suatu produk. Pada saat perkecambahan banyak senyawa yang berubah menjadi prekusor dan berkontribusi dalam rasa lezat (Winarsi, 2017). Sudarmadji et al. (2010) menyatakan bahwa asam amino hasil pemecahan protein dengan gula-gula reduksi membentuk senyawa rasa dan aroma makanan yang lezat.

h. Mutu Hedonik Tekstur

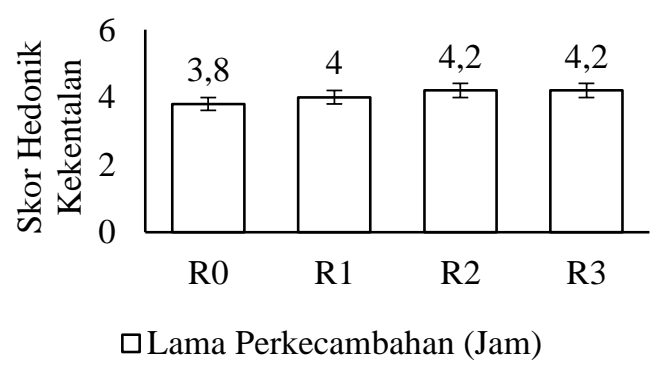

Gambar 4.8. Nilai Rata-rata Kesukaan Rasa Sukarah pada Perlakuan Lama Perkecambahan Keterangan: $\mathrm{R} 0=$ Kontrol; R1 = Sukarah dengan lama perkecambahan 8 jam; R2 = Sukarah dengan lama perkecambahan 16 jam; R3 = Sukarah dengan lama perkecambahan 24 jam. Skor: $1=$ Amat sangat tidak suka; $2=$ Sangat tidak suka; $3=$ Tidak Suka; $4=$ Antara suka dan tidak suka; $5=$ Suka; $6=$ Sangat suka; $7=$ Amat sangat suka; $\mathrm{n}$ $=50$. Angka yang diikuti huruf yang sama menunjukkan tidak berbeda nyata pada DMRT 5\%; Angka yang diikuti huruf yang berbeda menunjukkan ada perbedaan yang nyata pada DMRT 5\%.

Hasil uji Friedman menunjukkan tidak terdapat pengaruh lama perkecambahan terhadap kesukaan pada kekentalan sukarah $\quad(\mathrm{p}>0,05)$ (Gambar 4.8). Kemungkinan terkait dengan nilai mutu hedonik 
kekentalan sukarah yang tidak berbeda jauh yaitu di rentang 3,44,3 (tidak kental-sedikit kental) (Gambar 4.4). Namun demikian, terdapat kecendrungan susu yang dikecambahkan lebih disukai panelis karena memiliki viskositas yang lebih rendah atau encer. Hasil penelitian Yua Wea (2014) menunjukkan bahwa susu kacang hijau yang dikecambahkan lebih disukai panelis dibandikan dengan yang tidak dikecambahkan. Hal tersebut karena susu yang dikecambahkan lebih rendah kekentalannya dibanding yang tidak dikecambahkan

\section{Kadar Protein Terlarut Susu}

\section{Kecambah Kacang Merah}

Hasil uji F menunjukkan bahwa $p>0,05$ sehingga perlakuan lama perkecambahan tidak berpengaruh terhadap kadar protein terlarut sukarah. Hasil tersebut tidak selaras dengan penelitian Mardiyanto dan Sudarwati (2015) yang menunjukkan adanya peningkatan protein terlarut susu kecambah kacang kedelai pada jam 0 jam hingga jam ke-48. Hal ini dapat disebabkan karena kadar protein awal (bahan dasar) dari kacang-kacangan yang berbedabeda. Kadar protein awal kacang kedelai $35,1 \%$, sementara kadar protein awal kacang merah lebih kecil sebesar $24,37 \%$ (USDA, 2007). Oleh karena itu, peningkatan kadar protein terlarut kecambah kacang merah tidak tinggi. Kadar protein awal mempengaruhi tingkat hidrolisis protein pada masing-masing kecambah kacang-kacangan yang dihasilkan (Khairi dan Kanetro, 2014).

Pada penelitian ini suhu selama perkecambahan tidak dikondisikan sehingga kemungkinan terjadi penurunan atau peningkatan suhu dalam ruangan antar perlakuan, sedangkan suhu mempengaruhi aktivitas enzim protease selama perkecambahan. Pada suhu rendah, reaksi enzimatis berlangsung lambat, kenaikan suhu akan mempercepat reaksi, hingga suhu optimum tercapai dan reaksi enzimatis mencapai maksimum. Kenaikan suhu melewati suhu optimum akan menyebabkan enzim terdenaturasi dan menurunkan kecepatan reaksi enzimatis (Noviyanti et al., 2012). 
J. Gipas, November 2018, Volume 2 Nomor 2

ISSN 2599-0152 eISSn 2599-2465

http://jos.unsoed.ac.id/index.php/jgps

Oleh karena itu perlunya pengaturan suhu selama perkecambahan karena mempengaruhi aktivitas enzim.

Namun demikian, terdapat kecenderungan peningkatan kadar protein terlarut seiring dengan lama perkecambahan (Gambar 4.3). Kadar protein terlarut tertinggi terdapat dalam sukarah dengan lama perkecambahan 16 jam.

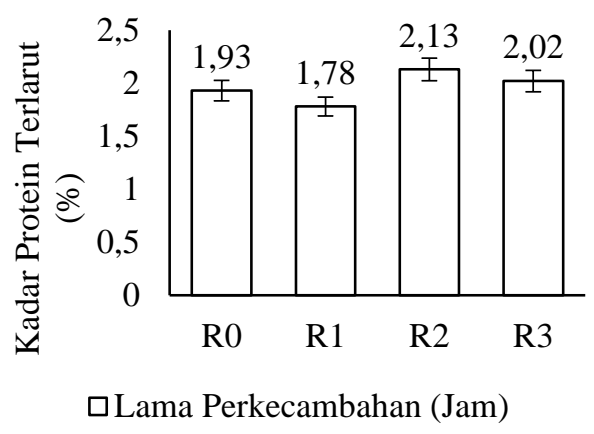

\section{Gambar 4.9. Pengaruh Lama Perkecambahan terhadap Kadar Protein Terlarut Sukarah.}

Keterangan:

$\mathrm{R} 0=$ Kontrol; $\mathrm{R} 1$ = Sukarah dengan lama perkecambahan 8 jam; R2 = Sukarah dengan lama perkecambahan 16 jam; R3 = Sukarah dengan lama perkecambahan 24 jam.

Penelitian ini menunjukkan adanya penurunan kadar protein telarut dari R0 ke R1, kemungkinan karena masih dalam masa adaptasi. Tahap pertama suatu perkecambahan benih dimulai dengan proses penyerapan air oleh benih, melunaknya kulit benih dan hidrasi dari protoplasma. Tahap kedua dimulai dengan kegiatan-kegiatan sel dan enzim-enzim serta naiknya tingkat respirasi yang membutuhkan energi sehingga terjadi penurunan protein terlarut (Sudarmaji, 2010). Selain itu, benih dan kadar zat antigizi yang masih tinggi di R0 mempengaruhi aktivitas enzim protease. Pada umumnya cara kerja inhibitor adalah dengan menyerang sisi aktif enzim sehingga enzim tidak dapat berikatan dengan substrat yang memnyebabkan fungsi katalitiknya terganggu (Tandi, 2010).

Terjadinya peningkatan kadar protein terlarut dari $\mathrm{R} 1$ ke $\mathrm{R} 2$ $(0,35 \%)$, karena perkecambahan akan mengaktifkan enzim protease (Anggrahini, 2007). Protein didegradasi oleh enzim protease menjadi asam-asam amino yang bersifat larut dengan berat molekul yang lebih kecil sehingga meningkatkan nilai cerna protein (Ojha et al., 2014). Ikatan-ikatan yang kuat antar komponen penyusun protein akan terlepas sehingga memungkinkan kadarnya 
J. Gipas, November 2018, Volume 2 Nomor 2

ISSN 2599-0152 eISSn 2599-2465

http://jos.unsoed.ac.id/index.php/jgps

meningkat, demikian pula daya cernanya sampai pada tahap asimilasi (Laetitia et al., 2005).

Penurunan kadar protein terlarut dari R2 ke R3 sebesar 0,11\%. Yua Wea et al. (2014) menyatakan bahwa penurunan protein terlarut selama perkecambahan terjadi karena telah memasuki tahap asimilasi. Asimilasi merupakan tahap akhir menggunakan cadangan makanan. Pada tahap ini asam amino disusun kembali menjadi protein baru sehingga protein terlarutnya mengalami penurunan. Protein yang terbentuk digunakan untuk pembentukan struktur baru sejalan dengan bertambahnya umur dalam tahapan perkecambahan (Pertiwi et al., 2013).

Sukarah yang dikecambahkan selama 16 jam memiliki mutu warna yang lebih cerah yang paling disukai oleh panelis. Aroma langunya pun sedikit tercium sehingga disukai oleh panelis. Adapun rasa dari sukarah yang dikecambahkan selama 16 jam memiliki tingkat manis dan kekentalan yang paling disukai bersama sukarah yang dikecambahkan selama 24 jam (Gambar 4.4).

Berdasarkan uji indeks efektifitas dengan bobot parameter protein terlarut 1 , aroma hedonik 0,9 ; rasa hedonik 0,8 ; warna hedonik 0,7; kekentalan hedonik 0,6 ; aroma mutu hedonik 0,5 ; rasa mutu hedonik 0,4; warna mutu hedonik 0,3; dan kekentalan mutu hedonik 0,2 didapatkan hasil nilai efektifitas tertinggi adalah R2 yaitu sukarah dengan lama perkecambahan 16 jam $(0,81)$ diikuti oleh sukarah dengan lama perkecambahan 24 jam $(0,78)$, sukarah dengan lama perkecambahan 8 jam $(0,2)$, dan sukarah yang tidak dikecambahkan $(0,1)$ (Lampiran 4).

Loliana dan Nadhiroh (2015) melaporkan bahwa rata-rata asupan energi, karbohidrat, dan lemak harian pada remaja obesitas lebih tinggi dibandingkan dengan remaja non obesitas. Sebagian besar remaja pada kelompok obesitas memiliki kecukupan energi, karbohidrat, dan lemak lebih tinggi dibandingkan dengan 
J. Gipas, November 2018, Volume 2 Nomor 2

ISSN 2599-0152 eISSn 2599-2465

http://jos.unsoed.ac.id/index.php/jgps

remaja non obesitas. Sukarah terbaik memiliki memiliki kadar air 88,4\%, abu 0,04\%, lemak $0,1 \%$, protein tinggi $6,54 \%$, dan karbohidrat rendah 4,48\%. Protein sukarah terbaik tiga kali lebih tinggi dibandingkan dengan SNI (1995) batas minimun protein susu kedelai (2\%). Hal tersebut menjadikan sukarah berpotensi menjadi minuman fungsional bagi remaja obesitas, seperti kita ketahui bahwa remaja memerlukan asupan protein yang tinggi untuk memfasilitasi perubahan biologis, fisiologis, dan psikologis yang terjadi. Winarsi melaporkan bahwa diet tinggi protein menghasilkan rasa kenyang lebih lama dibandingkan diet rendah protein, sehingga menekan asupan energi berikutnya. Hal ini terjadi karena tubuh tidak memiliki protein storage sehingga protein segera dimetabolisme menjadi energi. Selain itu, kadar lemak sukarah pun rendah yaitu 1/10 dibandingkan SNI (1995) batas minimun lemak susu kedelai (1\%). Kelebihan lain dari sukarah ini adalah dapat menjadi pengganti susu sapi bagi penderita lactose intolerance.

\section{KESIMPULAN.}

Lama

perkecambahan berpengaruh terhadap mutu hedonik warna, aroma, rasa, dan kekentalan sukarah. Semakin lama perkecambahan. Lama perkecambahan tidak berpengaruh terhadap kadar protein terlarut sukarah, namun seiring dengan lama waktu perkecambahan terdapat trend kenaikan kadar protein terlarut. Produk terbaik adalah sukarah hasil perkecambahan 16 jam yang mengandung kadar air $88,4 \%$, abu $0,04 \%$, lemak $0,1 \%$, protein $6,54 \%$, dan karbohidrat $4,48 \%$.

\section{DAFTAR PUSTAKA}

Aksara, E., 2012, Bebas Stress Usai Melahirkan, Jogjakarta, Javalitera Aprilianti, T., 2010, Kajian Sifat Fisikokimia dan Sensori Tepung Ubi Jalar Ungu (ipomoea batatas blackie) dengan Variasi Proses Pengeringan, Skripsi, Fakultas Pertanian Universitas Sebelas Maret, Surakarta.

Astawan, M., 2009, Sehat dengan Hidangan Kacang dan Biji bijian, Penebar Swadaya, Jakarta.

Khairi, E., dan Kanetro, B., 2014, Pengaruh Berbagai Kecambah KacangKacangan Terhadap Kadar Protein Terlarut Dan Asam Amino Bebas Limbah Cair Isolasi Protein, Jurnal Agri Sains, 5 (2) : 2086-7719.

Laetitia M.M., Joseph H.D., Josep D., Christian M., 2005, Physical, chemical and microbiological changes during natural fermentation of 'gowe", a sprouted or non sprouted sorghum beveragefrom West Africa, African Journal Biotechnol, 4 (6) : 467-496. 
Lewis, M.J., 2000, Physical Properties of Food and Food Processing System, Camelot Press, Canada.

Madiyanto T.C., dan Sudarwati S., 2015, Studi Nilai Cerna Protein Susu Kecambah Kedelai Varietas Lokal Secara In Vitro, Jurnal MIPA, 1 (5) : 1256-1264.

Marsono, Y., Paulus, W., dan Zuheid, N., 2002, Indeks Glikemik Kacangkacangan. Jurnal Teknologi dan Industri Pangan, 13 (3) : 13-16.

Mawardi, Y.S.A, Pramono, Y.B., dan Setiani, B.E., Kadar Air, Tanin, Warna dan Aroma Off-Flavour Minuman Fungsional Daun Sirsak (Annona Muricata)dengan Berbagai Konsentrasi Jahe (Zingiber Officinale), Jurnal Aplikasi Teknologi Pangan, 5 (3) : 94-98.

Montero, D., Walther, G., Perez-Martin, A., Roche, E., dam Vinet, A., 2011, Etiology and

Pathophysiology/prevention:

Endothelial dysfunction, inflammation, and oxidative stress in obese children and adolescent: marker and effect of lifestyle intervention, International Journal of Obesity, 30 (13) : 441-455.

Murugkar, D.A., 2014, Effect of sprouting of soybean on the chemical composition and quality of soymilk and tofu, Journal Food Sciences Technology, 51 (5) : 915-921.

Ojha, P., Karki, T.B., dan Maharjan, S., 2014, Effect of Sprouting in Physicochemical Properties of Tofu, Journal of Nutritional Health and Food Engineering, 1 (2) :00011.

Pertiwi, S.F., Aminah, S., dan Nurhidajah, 2013, Aktivitas Antioksidan, Karakteristik Kimia, dan Sifat Organoleptik Susu Kecambah Kedelai Hitam (Glycine soja) Berdasarkan Variasi Waktu Perkecambahan, Jurnal Pangan dan Gizi, 4 (8) : 10-21.

Rahmawati, W., Kusumastuti, Y.A., dan Aryanti, N., 2012, Karakterisasi Pati Talas (Colocasia esculenta L. Schott) Sebagai Alternatif Sumber Pati Industri di Indonesia, Jurnal Teknologi Kimia dan Industri, 1 (1) : 347-351.
Suarni dan Ubbe, U., 2005, Perbaikan Kandungan Nutrisi dan Sifat Fisiko Kimia Tepung Sorgum dengan Enzimatis ( $\alpha$-amilase) dari Kecambah Kacang Hijau, Prosiding Seminar Nasional Kimia p 92-95, Universitas Tadulako dan Forum Kerjasama Kimia KTI.

Sudarmadji , 2010, Analisa Bahan Makanan dan Pertanian, Liberty, Yogyakarta.

Sunkara, R., dan Verghese, M., 2014, Functional Foods for Obesity Management Food and Nutrition Sciences, Journal Food and Nutrition Sciences, 3 (1) : 1354-1364.

Tandi, E.J., 2010, Pengaruh Tanin Terhadap Ativitas Enzim Protease, Seminar Nasional Teknologi Peternakan, Universitas Hasanudin, Makasar.

Winarno, F.G., 2004, Kimia Pangan dan Gizi, PT Gramedia Pustaka, Jakarta.

Winarsi, H., 2017, Susu Kecambah Kedelai: Teknologi Pembuatan, Kandungan Gizi dan Senyawa Bioaktif, Universitas Jenderal Soedirman, Purwokerto.

Yua Wea, A.S., Widodo, R., dan Pratomo, Y.A., 2014, Evaluasi Kualitas Produk Susu Kecambah Kacang Hijau, Kajian Dari Umur Kecambah Dan Konsenterasi Na-CMC, Jurnal Teknik Industri Heuristic, 11 (1) : 1693-8232. 